\title{
INOVASI FLASHCARD BERBASIS TEKNOLOGI AR SEBAGAI ALAT PERMAINAN EDUKATIF DALAM MENINGKATKAN KECERDASAN BAHASA ANAK DI MASA PANDEMIC COVID-19
}

\author{
Siti Dela Soflianti ${ }^{1}$ Puspita Melati ${ }^{2}$ Aulia Rahmah $^{3}$ Milkhatun $^{4}$ RR. Deni Widjayatri ${ }^{5}$ \\ ${ }^{1}$ Pendidikan Anak Usia Dini, Universitas Pendidikan Indonesia \\ ${ }^{2}$ Pendidikan Anak Usia Dini, Universitas Pendidikan Indonesia \\ ${ }^{3}$ Pendidikan Anak Usia Dini, Universitas Pendidikan Indonesia \\ ${ }^{4}$ Pendidikan Anak Usia Dini, Universitas Pendidikan Indonesia
}

\begin{abstract}
ABSTRAK
Penelitian ini bertujuan untuk meningkatkan kecerdasan Bahasa anak melalui inovasi alat permainan edukatif Flashcard Berbasis Teknologi Augmented Reality dalam mengenal buah, sehingga dapat dimanfaatkan oleh para pendidik sebagai salah satu alternative alat permainan edukatif di masa pandemic covid-19. Penelitian ini menggunakan metode penelitian kualitatif deskriptif. Subyek penelitian berjumlah 2 anak usia dini yang masuk ke dalam kelompok A di Taman Kanak-Kanak (TK). Metode pengumpulan data yang digunakan adalah observasi, tes atau pengujian dan dokumentasi. Data yang akan diolah oleh penulis yaitu dari data yang dihasilkan riset pengujian. Originalitas pada penelitian ini yakni inovasi produk alat permainan edukatif Flashcard Berbasis Augmented Reality mengenai buah. Hasil Penelitian menunjukan bahwa anak mengalami peningkatan kecerdasan bahasa dalam mengetahui dan mengenal kosa kata baru yaitu nama-nama buah melalui alat permainan edukatif flashcard berbasis teknologi augmentasi reality. Maka dari hasil penelitian tersebut, dapat diketahui alat permainan edukatif Flashcard berbasis teknologi (AR) mengenai nama buah-buahan dapat menjadi solusi di masa pandemic covid-19. Sebab, dimensi object $3 D$ yang dipancarkan pada Flashcard melalui teknologi augmented reality memberikan kesan realistis.
\end{abstract}

Kata Kunci: anak usia dini, APE, flashcard, augmented reality

\section{PENDAHULUAN}

Pendidikan Anak Usia Dini (PAUD), merupakan pendidikan awal non-formal yang dilaksanakan oleh suatu lembaga pendidikan sebelum memasuki pendidikan formal $^{1}$ atau dianggap sebagai pendidikan pra-sekolah ${ }^{2}$. Berdasarkan Klasifikasi Standar International (ISCED), Pendidikan Anak Usia Dini (PUD) dimulai sejak anak berusia 3-6 tahun (ISCED Level 0). Racangan ISCED level 0 merupakan rancangan yang dibuat guna melengkapi kebutuhan pendidikan dan perkembangan anak-anak mulai berusia 3 tahun $^{3}$.

\footnotetext{
${ }^{1}$ Oluwafemi, Nma., Osita., \& Olugbenga. (2014). Implementation of Early Childhood Education: A Case Study in Nigeria. Universal Journal of Educational Research, 2(2), 119-125. doi:DOI: 10.13189/ujer.2014.020203

${ }^{2}$ H. Khairi. (2018). Karakteristik Perkembangan Anak Usia Dini Dari 0-6 Tahun. Jurnal Warna, 2. Retrieved from https://ejournal.iaiig.ac.id/index.php/warna/article/view/87

${ }^{3}$ Bennett. (2008). Benchmarks For Early Childhood Services In Oecd Countries. UNICEF Innocenti Research Centre.
} 
Di Indonesia sendiri, menurut Peraturan Menteri Pendidikan Dan Kebudayaan (PERMENDIKBUD) tahun 2013 berdasarkan Undang-Undang Nomor 20 tahun 2003 tentang Sistem Pendidikan Nasional ialah "Pendidikan Anak Usia Dini, yang selanjutnya disingkat PAUD, Merupakan suatu upaya pembinaan yag ditujukan kepada anak sejak lahir sampai dengan usia 6 (enam) tahun yang dilakukan melalui pemberian rangsangan pendidikan untuk membantu pertumbuhan dan perkembangan jasmani dan rohani agar anak memiliki kesiapan dalam memasuki pendidikan lebih lanjut. ${ }^{4}$.

Dari beberapa pendapat mengenai definisi pendidikan anak usia dini di atas, dapat diketahui bahwa pendidikan anak usia dini dilakukan sebagai suatu program pendidikan untuk membantu memberikan rangsangan atau stimulasi perkembangan rohani dan jasmani anak yang memiliki rentan usia 0-6 tahun. Rancangan stimulasi perkembangan untuk anak usia dini dilakukan, guna membantu anak usia dini di masa keemasannya atau dikenal dengan golden age yang di mulai dari periode 6 tahun pertama anak (masa kanak-kanak) dan menurut pada masa tersebut adalah waktu yang paling tepat untuk menepatkan dasar stimulasi "berbagai potensi seperti fisik, kognitif, bahasa, seni sosial, spiritual, konsep diri, disiplin diri, serta kemandirian" 5 .

Berdasarkan penjelasan di atas, bahasa merupakan aspek penting dalam perkembangan anak dikarenakan anak membutuhkan komunikasi dan interaksi dalam membangun hubungan sosial yang baik serta dapat mengeluarkan pendapatnya kepada orang lain ${ }^{6}$. Yektiningsih (2020) menjelaskan bahwa seluruh perkembangan berkaitan dengan kemampuan berbahasa sebab pengaruhnya kemampuan berbahasa dengan kemampuan kognitif, sensori motor, psikologis, dan emosi ${ }^{7}$. Dari hal tersebut penting dilakukan stimulasi perkembangan bahasa anak pada Pendidikan Anak Usia (PAUD).

Namun, Pendidikan Anak usia dini (PAUD) saat ini mengalami kendala dalam proses belajar mengajar dikarenakan seluruh dunia mengalami perkara kasus yang sama yakni pandemic covid-19 selama dua tahun terakhir sejak kemunculan pertamanya di Wuhan, China $^{8}$. Munise Duran (2020) meninjau bahwa 191 negara di dunia melakukan kebijakan untuk menutup akses sekolah dimasa pandemik. Pemerintah Indonesia pun melakukan kebijakan yang sama dimasa pandemik yakni Pembelajaran Jarak Jauh (PJJ) mulai dari Pendidikan Anak Usia Dini (PAUD) sampai Sekolah Menengah Atas (SMA). Pembelajaran

${ }^{4}$ Kemendikbud. Retrieved from https://simpuh.kemenag.go.id/regulasi/permendikbud_146_14 2014.

${ }^{5}$ Khairi. Karakteristik Perkembangan Anak Usia Dini Dari 0-6 Tahun. Jurnal Warna, 2. 2018 Retrieved from https://ejournal.iaiig.ac.id/index.php/warna/article/view/87, 16.

${ }^{6}$ Renawati, \& Suyadi. (2021). Pengembangan Kreativitas Anak Usia Dini di Masa Pandemi Covid 19 melalui Alat Permainan Edukatif Papan Pintar dari Kulit Kerang. Journal on Early Childhood, 22 - 27. doi:https://doi.org/10.31004/aulad.v4i1.92

${ }^{7}$ Yudia, Yudiemawati, \& Maemunah, (2018). Pengaruh Pemberian Stimulasi Oleh Orang Tua Terhadap Perkembangan Bahasa Pada Anak Usia Toddler Di Paud Asparaga Malang. Jurnal Ilmiah Keperawatan, 3(1). doi:https://doi.org/10.33366/nn.v3i1.828

8 J. Lee. (2020). Mental health effects of school closures during COVID-19. The Lancet Child \& Adolescent Health. doi:https://doi.org/10.1016/S2352-4642(20)30109-7 
Jarak Jauh (PJJ) tidak mudah dilaksanakan untuk anak usia dini, sebab anak usia dini baru memulai pendidikan pertama di sekolah ${ }^{9}$.

Di masa Pendidikan Anak Usia Dini (PAUD) juga mereka baru memulai melakukan aktivitas sosialisasi dengan teman sebaya dan bertemu guru yang akan mendidiknya di sekolah. Namun aktivitas tersebut tidak dapat terlaksana karena pandemic. Selain itu, Alat permainan edukatif memiliki peranan penting dalam Pendidikan Anak Usia Dini (PAUD) sebagai media stimulant yang membantu proses penyampaian pembelajaran di sekolah ${ }^{10}$. Akibat pandemic, sarana pembelajaran seperti Alat permainan edukatif yang dimiliki anak di rumah sangat terbatas atau bahkan kurang dibandingkan dengan di sekolah. Di lain hal, mulai ditiadakan kegiatan luar sekolah atau study tour seperti mengunjungi kebun binatang untuk memperkenalkan jenis-jenis hewan secara nyata ${ }^{11}$. Hal tersebut menjadi permasalahan dan tantangan baru bagi pendidik.

Sesuai dengan permasalahan tersebut, pendidik membutuhkan alat permainan yang dapat di akses dengan mudah di rumah peserta didik dengan waktu yang bersamaan, hal tersebut dapat terjadi sekarang berkat adanya Technology Augmented Reality. Teknologi Augmented Reality merupakan teknologi yang merujuk pada augmentasi objek virtual ke tampilan aliran video dari dunia nyata melalui bantuan perangkat gadget atau computer dengan kata lain teknologi tersebut menyajikan interaktif antarmuka sehingga pengguna dapat berinteraksi secara bersamaan dengan dunia nyata dan objek virtual secara alami ${ }^{12}$.

Perkembangan Augmented Reality sudah semakin pesat, berbagai sektor memakai produk AR dengan keperluan yang berbeda seperti pemasaran, hiburan, tamasya dan pariwisata, fashion, pendidikan dan medis ${ }^{13}$ dalam sektor bidang pemasaran, contoh produk (AR) ialah Le Bar Guide yang menyiadakan fitur navigasi guna menghantarkan penggunannya ke bar yang terdapat bir Stella Artois terdekat ${ }^{14}$. Dalam sektor bidang entertainment, Nicholas Cooper, Aaron Keatley, Maria Dahlquist, SimonMann, Hannah Slay, Joanne zucco, Ross Smith \& Bruce H. Thomas (2004) membuat sebuah games permainan catur asli cina berbasis Augmented Reality yang dinamakan dengan ARCC. Dalam sektor bidang pariwisata, produk

${ }^{9}$ Wardani, A., \& Ayriza, Y. (2020, ). Analisis Kendala Orang Tua dalam Mendampingi Anak Belajar di Rumah Pada Masa Pandemi Covid-19. Jurnal Obsesi : Jurnal Pendidikan Anak Usia Dini, 5(1), 772-782. doi: 10.31004/obsesi.v5i1.705

${ }^{10}$ Hasmalena, Rukiyah, Syafdaningsih, Utami, F., Rantina, M., Karnita, A., \& Munawaroh, A. (2021). Pelatihan Pembuatan Alat Permainan Edukatif Berbasis Pendekatan. Jurnal Pengabdian Masyarakat, 3( 4), 332337

11 Pandanwangi, A. (2020). Upaya Perupa dalam Menyikapi Pandemi Covid 19. Prosiding Seminar Nasional Hardiknas. Retrieved from http://proceedings.ideaspublishing.co.id/index.php/hardiknas/article/view/14

12 Awang Rambli, D., Matcha, W., \& Sulaiman, S. (2013). Fun Learning with AR Alphabet Book for Preschool Children. ScienceDirect, 25, 211 - 219. doi:10.1016/j.procs.2013.11.026

13 Tambunan.,S.Par.,M.Sc1, E., \& Masatip.,S.Sos.,MM.Par, D. (2020). Konsep Augmented Reality Sebagai Pengembangan Pemasaran Pariwisata dalam Menghadapi New Normal Masa Pandemi Covid-19. Jurnal Ilmiah Akomodasi Agung, 7(2). doi:https://doi.org/10.51827/jiaa.v7i2.47

${ }^{14}$ Carmigniani, J., \& Furht, B. (2011). Augmented Reality: An Overview. Springer Science+Business Media, 3-46. doi:10.1007/978-1-4614-0064-6_1 
(AR) berfungsi memberikan pengunjung informasi tambahan tentang suatu objek virtual dengan kata lain, (AR) dapat menyediakan documenter yang menceritakan peristiwa bersejarah dengan menampilkan grafik objek 3-D secara virtual dengan pembahan fitur suara didalamnya $^{15}$. Dalam sektor bidang medis, Christoph Bichlmeier, Felix Wimmer, Sandro Michael Heining, Nassir Navab (2007) memperkenalkan sebuah fitur sistem (AR) untuk menampilkan anatomi virtual melalui kulit yang nyata. Dalam sektor pendidikan, dosen atau mahasiswa melakukan praktik lab dengan menggunakan (AR) guna mengefesiensikan waktu dan menghemat budget ${ }^{16}$ selain itu, ada pula produk (AR) yang dibuat oleh Yulia Khusnul Hamidiyah \& Yoyok Yermiandhoko ${ }^{17}$. Hamidiyah dan Yermiandhoko (2020) yakni kartu bacaan berbasis (AR) untuk mengenal keberagaman rumah adat. Sesuai dengan penelitian tersebut peneliti mengembangkan sebuah alat permainan yaitu flashcard berbasis augmented reality yang berisikan hal-hal berikut:

1. Flashcard mengenai nama-nama buah untuk menambah kosa kata baru anak.

2. Produk (AR) yang disajikan khusus untuk Pendidikan Anak Usia Dini.

3. Desain warna flashcard yang menarik untuk anak usia dini.

4. Alat permainan edukatif yang dapat digunakan dirumah dalam proses pembelajaran jarak jauh.

5. Alat permainan yang cocok digunakan dalam masa pandemic covid-19

Maka dari itu, tujuan dari penelitian ini untuk mengembangkan alat permaianan edukatif berbasis Teknologi Augmented Reality sebagai inovasi alat permainan edukatif khusus untuk Pendidikan Anak Usia Dini (PAUD) agar dapat dimanfaatkan oleh para pendidik sebagai salah satu alternative media pembelajaran dimasa pandemik. Originalitas dalam penelitian ini ialah pengenalan inovasi alat permaianan edukatif untuk Anak Usia Dini yakni berupa flashcard atau kartu bacaan mengenai buah-buahan. Flashcard buah-buahan berbasis Teknologi Augemented Reality adalah flashcard yang memiliki sensor software yaitu AR guna memunculkan objek buah melalui flashcard buah sehingga objek buah yang terdapat pada flashcard dapat terlihat nyata.

\section{METODE}

Penelitian ini menggunakan pendekatan kuanlitatif dengan metode deskriptif analisis berbentuk frase penjabaran dari hasil penelitian mengenai meningkatkan kecerdasan bahasa anak usia dini melalui alat permainan edukatif flashcard berbasis teknologi augmented reality. Selain itu, penelitian ini menggunajab trigulasi sebagai teknik analisis data serta

\footnotetext{
${ }^{15}$ Berryman, D. (2012). Medical reference services quarterly. Taylor \& Francis Online, 31(2), 212-218. doi:https://doi.org/10.1080/02763869.2012.670604

16 Gutierrez, M. J., Guinters, E., \& Lopez, D. P. (2012). Improving strategy of self-learning in engineering: laboratories with. ScienceDirect, 51, 832-839. doi:https://doi.org/10.1016/j.sbspro.2012.08.249

${ }^{17}$ Carmigniani, J., \& Furht, B. (2011). Augmented Reality: An Overview. Springer Science+Business Media, 3-46. doi:10.1007/978-1-4614-0064-6_1
} 
pengumpulan data berupa observasi dan dokumentasi ${ }^{18}$. Subjek penelitian berjumlah dua anak usia dini berinsial AN dan AZ yang keduanya berusia 5 tahun. Adapun objek penelitian menggunakan flashcard buah-buahan berbasis Augmented Reality. Lokasi penelitian dilakukan di salah satu rumah warga Kampung Senapan Ciwaru, Kecamatan Ciomas, Kabupaten Serang, Provinsi Banten. Penelitian ini menggunakan indikator penilaian yang sesuai dengan STTPA dalam ruang lingkup aspek perkembangan bahasa untuk umur 4-5 tahun.

\section{HASIL DAN PEMBAHASAN}

Tahapan dalam membuat Alat permainan edukatif flashcard buah-buahan berbasis augmented reality di awal dengan mendesain flashcard mengenai buah seperti semangka, strawberry, apel, cherry, pisang, dan alpukat. Desain tersebut disesuaikan dengan kententuan Platform Vuforia yang berfungsi untuk menilai penanda gambar layak untuk diaugmentasi atau tidak ditandai dengan rating bintang yang tersedia, jika rating sudah mencapai 3-5 maka gambar tersebut dapat digunakan. Adapun kententuan penanda gambar pada Platform Vuforia sebagai berikut ${ }^{19}$ :

1. Perincian gambar harus detail.

2. Gambar memiliki kontras yang bagus, baik area terang dan gelap

3. Pola tidak berulang.

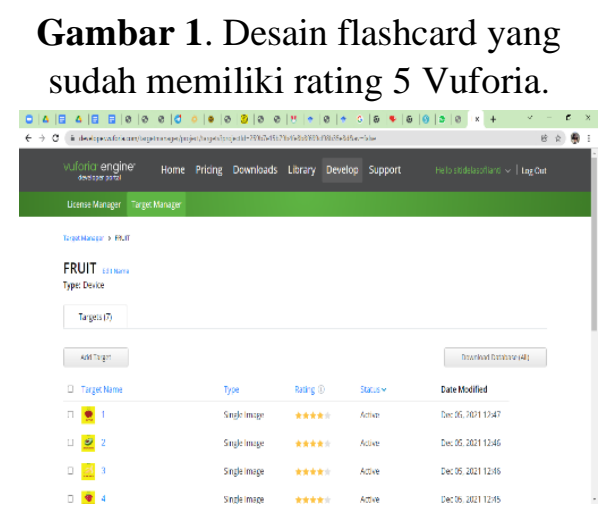

Sumber: Dokumentasi Website Vuforia

\footnotetext{
${ }^{18}$ Renawati, \& Suyadi. (2021). Pengembangan Kreativitas Anak Usia Dini di Masa Pandemi Covid 19 melalui Alat Permainan Edukatif Papan Pintar dari Kulit Kerang. Journal on Early Childhood, 22 - 27. doi:https://doi.org/10.31004/aulad.v4i1.92

${ }^{19}$ Andriyat, R. (2019). Basic AR Module With Vuforia and Unity. 1-32. Retrieved from https://staff.uniku.ac.id/rioandriyat
} 
Setelah mendapatkan rating 5, maka tahap selanjutnya membuat flashcard dengan bahan yang mudah ditemukan dirumah yaitu kertas flashcard yang sudah dicetak, kardus, gunting, dan lem. Kegiatan menempel dan menggunting dapat dilakukan bersama anak untuk melatih rasa ingin tahu anak mengenai Alat permainan edukatif yang sedang dibuat dengan hal tersebut juga dapat berdampak pada kecerdasan bahasa anak.

Gambar 2. Kartu Flashcard terbuat dari kardus

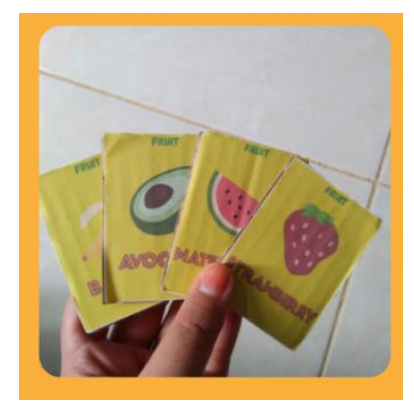

Sumber: Dokumentasi Produk Penelitian

Langkah selanjutnya adalah memproses software aplikasi augmented reality melalui Platform Unity 3D. 3D pada hardware laptop atau komputer sedangkan, hardware smartphone belum mampu dilakukan proses penginstalan platform game engine tersebut.

Gambar 3. Download Platform Unity 3D

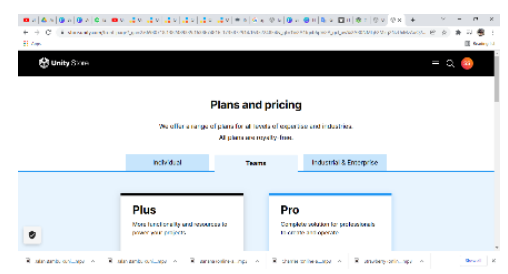

Sumber: Dokumentasi Platform Unity 3D

Spesifikasi laptop atau komputer yang dapat mengoperasikan platform Unity $3 \mathrm{D}^{20}$.

1. Standar Minimum untuk system operasi windows

a) Microsoft Windows 7/8/10 (32 bit dan 36 bit)

b) 3GB RAM (Random Access Memory).

c) Saat melakukan installasi terdapat 2GB kosong yang tersedia dalam hardware laptop maupun komputer.

${ }^{20}$ Umal, M. K. (2019, Augustus 14). Cara Mendapatkan Aplikasi Unity 3D Dan Aplikasi Pendukungnya. Retrieved from Jokam Informatika: https://jokam-informatika.com/blog/cara-mendapatkan-aplikasi-unity-3ddan-aplikasi-pendukungnya-untuk-membuat-game-keren/ 
d) $1280 \times 800$ screen resolusi

2. Standar Minimun untuk system operasi OS
a) Mac OS X 10.10 (Yosemite)
b) 3GB RAM (Randim Access Memory)
c) Saat melakukan installasi terdapat $2 \mathrm{~GB}$ kosong yang tersedia dalam hardware laptop maupun komputer.
d) $1280 \times 800$ screen resolusi

3. Standar Minimun Linux
a) GNOME atau KDE Desktop semua varian
b) 64 bit dan 32 bit aplikasi distribusi
c) GNU C Library 2.19 .
d) Saat melakukan installasi terdapat 2GB kosong yang tersedia dalam hardware laptop maupun komputer.
e) $1280 \times 800$ screen resolusi.

Tahap selanjutnya adalah menambahkan program seperti AR Camera yang berguna menampilkan object 3D di aplikasi android mobile, Image Target yang akan menampilkan desain flashcard atau market sebagai penanda object 3D dan terakhir membuat programman script suara yang berguna untuk mengisi suara pada object sehingga pada saat flashcard diarahkan melalui gawai berbasis android akan memunculkan object 3D serta suara yang telah diisi. Hal tersebut berguna untuk membantu anak usia dini dalam meningkat kecerdasan bahasa melalui suara yang mengenalkan kosakata baru yaitu nama-nama buah. Setelah menambahkan program maka mindahkan software tersebut dalam bentuk Aplikasi Augmented Reality berbasis android sehingga dapat diakses melalui gawai. Setelah semua proses pembuatan selesai, anak berinsial AN dan AZ mulai bermain dan belajar melalui alat permainan edukatif flashcard buah-buahan berbasis augmented reality ini.

Gambar 4. Flashcard yang sudah di program.

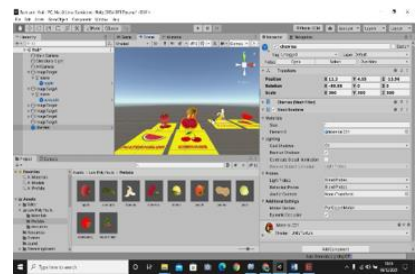

Sumber: Dokumentasi Proses Pengerjaan 
Gambar 5. Contoh flashcard

AR buah alpukat.

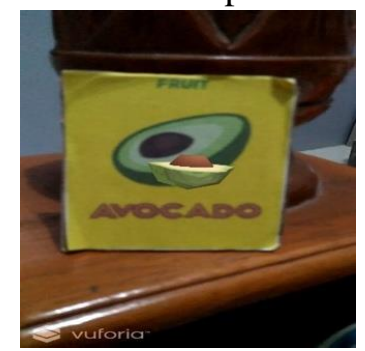

Sumber: Dokumentasi Hasil Pengerjaan

Penilaian pun dilakukan melalui indikator STTPA aspek perkembangan bahasa anak usia 4-5 tahun dan hasil indikator penilaian yang dilakukan kepada AN dan AZ dapat diketahui pada tabel 1.

Tabel 1. Hasil penilaian

Instrumen Penilaian

\begin{tabular}{|c|c|c|c|c|c|c|}
\hline \multirow{2}{*}{$\begin{array}{c}\text { Subjek } \\
\text { Penelitian }\end{array}$} & \multirow{2}{*}{$\begin{array}{l}\text { Ruang } \\
\text { Lingkup }\end{array}$} & \multirow[t]{2}{*}{ Indikator Penilaian } & \multicolumn{4}{|c|}{ Penilaian } \\
\hline & & & BB & MB & BSH & BSB \\
\hline AN & \multirow{8}{*}{$\begin{array}{l}\text { Aspek } \\
\text { Perkembangan } \\
\text { Bahasa }\end{array}$} & \multirow{2}{*}{$\begin{array}{l}\text { Bertanya dengan menggunakan lebih dari } 2 \\
\text { kata-kata tanya seperti: apa, mengapa, } \\
\text { bagaimana, dimana }\end{array}$} & & $\mathrm{V}$ & & \\
\hline AZ & & & & & $\bar{V}$ & \\
\hline AN & & \multirow{2}{*}{$\begin{array}{l}\text { Menggunakan kalimat pendek untuk } \\
\text { menyatakan apa yang dilihat dan dirasa. }\end{array}$} & & & $\mathrm{V}$ & \\
\hline AZ & & & & & $\mathrm{V}$ & \\
\hline AN & & \multirow{2}{*}{$\begin{array}{l}\text { Menceritakan kembali apa yang didengar } \\
\text { dengan kosakata yang terbatas }\end{array}$} & & & & $\mathrm{V}$ \\
\hline AZ & & & & & & V \\
\hline $\mathrm{AN}$ & & \multirow{2}{*}{$\begin{array}{l}\text { Mengenal suara-suara hewan/benda yang ada di } \\
\text { sekitarnya }\end{array}$} & & & $\mathrm{V}$ & \\
\hline AZ & & & & & $\mathrm{V}$ & \\
\hline
\end{tabular}

Sumber: Data penelitian

Berdasarkan hasil penilaian pada table 1, dapat diketahui indikator penilaian yang dilakukan pada AN dan AZ sama sesuai usia keduanya yaitu 5 tahun serta keduanya berada pada kelompok A di Taman Kanak-Kanak. Selain itu, penilaian dilakukan dengan 4 faktor yaitu BB (Belum Berkembang), MB (Mulai Berkembang), BSH (Berkembang Sesuai Harapan), BSB (Berkembang Sangat Baik). Ditinjau dari hasil penilaian, AZ dalam indikator Ke-1 yaitu bertanya dengan menggunakan lebih dari 2 kata tanya seperti: apa, mengapa, bagaimana, dimana AN mendapat penilaian MB (Masih Berkembangan) sedangkan AZ mendapat penilaian BSH (Berkembang sesuai Harapan) hal tersebut disebabkan saat peneliti memberi instruksi AZ lebih sering bertanya dibandingkan AN. Dalam Indikator ke-2 yaitu menggunakan kalimat pendek untuk menyatakan apa yang dilihat dan dirasakan, AZ dan AN memiliki penilaian yang sama yaitu BSH (Berkembang Sesuai Harapan) sebab AZ dan AN saat melihat object $3 D$ buah dan suara penyebutan buah muncul pada masing-masing 
flashcard yang diarahkan dengan gawai peneliti, memacu diri mereka mengatakan hal yang serupa dengan suara buah yang terdengar saat object 3D buah muncul. Di indikator ke-3 yaitu menceritakan kembali apa yang didengar dengan kosakata terbatas, keduanya mendapat penilian BSB (Berkembang Sangat Baik) karena setelah selesai bermain alat permainan edukatif flashcard buah-buahan berbasis teknologi augmentasi reality peneliti menanyakan terkait nama-nama buah yang telah diamati melalui flashcard tersebut dan keduanya dapat menjelaskan kembali buah-buah yang terdapat dalam flashcard yaitu strawberry, cherry, alpukat, pisang, semangka, dan apel. Pada indikator terakhir yaitu mengenal suara-suara hewan atau benda yang ada di sekitarnya, keduanya mendapat penilaian BSH (Berkembang Sesuai Harapan) sesuai dengan peninjauan indikator sebelumnya bahwa sudah dapat menjelaskan kembali mengenai nama-nama buah dengan sangat baik maka dalam penilain indakator ini anak sudah sangat baik mengenal nama-nama buah sesuai dengan suara yang muncul pada object 3D buah. Berdasarkan hasil penilaian dapat diketahui bahwa AN dan AZ mengalami peningkatan dalam mengetahui dan mengenal nama-nama buah melalui alat permainan edukatif flashcard berbasis teknologi augmentasi reality yang dapat diakses oleh anak saat dirumah dengan bimbingan orang tua. Pentingnya peran orang tua dalam masa pandemic covid-19 dalam pembelajaran jarak jauh dengan mendampingi anaknya, maka dari itu dibutuhkan kerja sama orang tua dan guru untuk menghidupkan suasana pembelajaran menyenakan di masa pandemic covid-19 yang bisa dilakukan dengan alat permainan edukatif flashcard buah-buahan berbasis augmented reality untuk meningkatkan kecerdasan bahasa anak usia dini. Kegiatan bermain flashcard buah-buahan berbasis augmented reality merupakan kegiatan yang menyenangkan bagi anak. Alat permainan ini melibatkan kosa kata baru serta animasi buah yang menarik baik pada desain flashcard maupun object 3D. Dengan begitu stimulant kecerdasan bahasa dapat berkembang dengan baik. Di lain hal, metode pembelajaran yang inovatif di masa pandemic covid-19 karena menggambungkan pembelajaran non-digital melalui flashcard dan pembelajaran digital yaitu melalui aplikasi augmented reality berbasis android mobile. Menggunakan flashcard buah-buahan berteknologi augmented reality tidak akan meninggalkan pembelajaran non-digital karena perkembangan teknologi pendidikan tetapi dapat berjalan beriringan dengan pembelajaran digital serta anak tidak mudah merasakan bosan dan jenuh dalam proses pembelajaran dengan menggunakan alat permainan edukatif ini. 
Gambar 6. Az dan An sedang melihat 3D objek buah

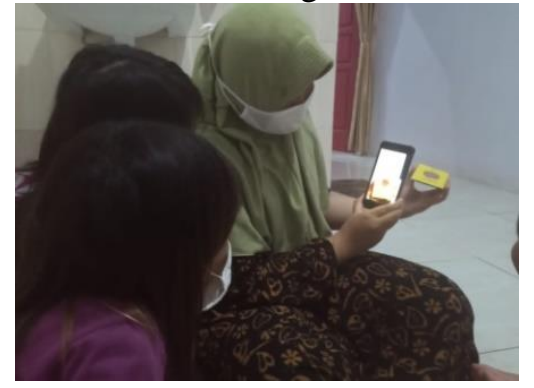

Sumber: Dokumentasi Uji Coba APE

Novita (2020) memaparkan bahwa kecerdasan bahasa pada anak dapat meningkatkan kemampuan anak dalam menerima dan memahami pengetahuan. Alat permainanan flashcard buah-buahan berbasis teknologi augmented reality disesuaikan dengan karakteristik anak yang lebih mudah meniru dan mengamati lingkungan sekitar dengan mendengarkan dan mengingat kata-kata yang diucapkan ${ }^{21}$. Dari perolehan bahasa tersebut anak dapat mengucapkan dan mengingat kosa kata baru di hidupnya ${ }^{22}$. Maka dari itu, alat permainan edukatif ini hadir untuk membantu anak dalam memahami, membaca, serta mengenal suara dari kosa kota yang baru anak ketahui serta melalui alat permainan ini, membuktikan bahwa anak berantusias dalam meningkat kecerdasan bahasa.

\section{KESIMPULAN}

Diadakannya pendidikan anak usia dini untuk memberikan rangsangan atau stimulasi anak usia dini. Stimulasi sangat diperlukan anak usia dini guna mengembangkan aspek bahasa, kognitif, sensori motor, seni dan sosial emosional sebab pada tahap tersebut anak sedang berada do fase golden age. Selain itu perkembangan bahasa memiliki faktor penting dalam meningkatkan aspek perkembangan lain. Maka dari itu, dibutuhkan stimulasi yang sesuai dengan karakteristik anak. Stimulasi tersebut dapat dilakukan melalui alat permainan edukatif Flashcard Buah Berbasis Augmented Reality. Pembelajaran melalui alat permainan edukatif Flashcard berbasis augmented reality mengenai nama-nama buah dapat menjadi solusi pembelajaran jarak jauh di masa pandemic covid-19 dalam meningkatkan kecerdasan berbahasa pada anak.

${ }^{21}$ Renawati, \& Suyadi. (2021). Pengembangan Kreativitas Anak Usia Dini di Masa Pandemi Covid 19 melalui Alat Permainan Edukatif Papan Pintar dari Kulit Kerang. Journal on Early Childhood, 22 - 27. doi:https://doi.org/10.31004/aulad.v4i1.92

${ }^{22}$ Febiola, S., \& Yulsyofriend. (2020). Penggunaan Media Flash Card terhadap Kemampuan Berbicara Anak Usia Dini. Jurnal Pendidikan Tambusai, 4(2). doi:https://doi.org/10.31004/jptam.v4i2.566 


\section{UCAPAN TERIMA KASIH}

Peneliti mengucapkan terima kasih kepada kedua orang tua dan anak yang telah turut membantu proses penelitian ini serta seluruh pihak yang terkait dalam penelitian ini.

\section{DAFTAR PUSTAKA}

Andriyat, R. (2019). Basic AR Module With Vuforia and Unity. 1-32. Retrieved from https://staff.uniku.ac.id/rioandriyat

Awang Rambli, D., Matcha, W., \& Sulaiman, S. (2013). Fun Learning with AR Alphabet Book for Preschool Children. ScienceDirect, 25, $211-219$. doi:10.1016/j.procs.2013.11.026

Bennett, J. (2008). Benchmarks For Early Childhood Services In Oecd Countries. UNICEF Innocenti Research Centre.

Bennett, J. (2008). Benchmarks for Early Childhood Services in OECD Countries. United Nations Children's Fund, 106. doi:https://doi.org/10.18356/53c9dc0e-en

Berryman, D. (2012). Medical reference services quarterly. Taylor \& Francis Online, 31(2), 212-218. doi:https://doi.org/10.1080/02763869.2012.670604

Bichlmeier, C., Wimmer, F., Heining, S. M., \& Navab, N. (2007). Contextual Anatomic Mimesis Hybrid In-Situ Visualization Method for Improving Multi-Sensory Depth Perception in Medical Augmented Reality. IEEE and ACM International Symposium on Mixed and Augmented Reality. doi:https://doi.org/10.1109/ISMAR.2007.4538837

Carmigniani, J., \& Furht, B. (2011). Augmented Reality: An Overview. Springer Science+Business Media, 3-46. doi:10.1007/978-1-4614-0064-6_1

Cooper, N., Keatley, A., Mann, S., Dahlquist, M., Slay, H., \& Zucco, J. (2004). Augmented Reality Chinese Checkers. ACM SIGCHI International Conferenceon Advances in Computer Entertainment Tecnology, 117-126. doi:https://doi.org/10.1145/1067343.1067357

Duran, M. (2021). The Effects of COVID-19 Pandemic on Preschool Education. Research Article, 7(2), 249 - 260. doi:10.12973/ijem.7.2.249

Febiola, S., \& Yulsyofriend. (2020). Penggunaan Media Flash Card terhadap Kemampuan Berbicara Anak Usia Dini. Jurnal Pendidikan Tambusai, 4(2). doi:https://doi.org/10.31004/jptam.v4i2.566

Gutierrez, M. J., Guinters, E., \& Lopez, D. P. (2012). Improving strategy of self-learning in engineering: laboratories with. ScienceDirect, 51, 832-839. doi:https://doi.org/10.1016/j.sbspro.2012.08.249

Hamidiyah, Y. K., \& Yermiandhoko, Y. (2020). PENGEMBANGAN MEDIA PEMBELAJARAN AUGMENTED REALITY BERBASIS ANDROID MATERI KERAGAMAN RUMAH ADAT KELAS IV SEKOLAH DASAR. Jurnal Penelitian Pendidikan Guru Sekolah Dasar, 8(5), 928-938. Retrieved from https://ejournal.unesa.ac.id/index.php/jurnal-penelitian-pgsd/article/view/35950 
Hasmalena, Rukiyah, Syafdaningsih, Utami, F., Rantina, M., Karnita, A., \& Munawaroh, A. (2021). Pelatihan Pembuatan Alat Permainan Edukatif Berbasis Pendekatan. Jurnal Pengabdian Masyarakat, 3( 4), 332-337.

Kemendikbud. (2014). Retrieved https://simpuh.kemenag.go.id/regulasi/permendikbud_146_14

Khairi, H. (2018). Karakteristik Perkembangan Anak Usia Dini Dari 0-6 Tahun. Jurnal Warna, 2. Retrieved from https://ejournal.iaiig.ac.id/index.php/warna/article/view/87

Lee, J. (2020). Mental health effects of school closures during COVID-19. The Lancet Child \& Adolescent Health. doi:https://doi.org/10.1016/S2352-4642(20)30109-7

Oluwafemi, O. L., Nma, A., Osita, O., \& Olugbenga. (2014). Implementation of Early Childhood Education: A Case Study in Nigeria. Universal Journal of Educational Research, 2(2), 119-125. doi:DOI: 10.13189/ujer.2014.020203

Oluwafemi, O., Nma, A., Osita, O., \& Olugbenga, O. (2014). Implementation of Early Childhood Education:. Universal Journal of Educational Research, 2(2), 119-125. doi: 10.13189/ujer.2014.020203

Osho Lauretta Oluwafemil, A. N. (2014). Implementation of Early Childhood Education: A Case Study in Nigeria. Universal Journal of Educational Research.

Pandanwangi, A. (2020). Upaya Perupa dalam Menyikapi Pandemi Covid 19. Prosiding Seminar Nasional Hardiknas. from http://proceedings.ideaspublishing.co.id/index.php/hardiknas/article/view/14

Renawati, \& Suyadi. (2021). Pengembangan Kreativitas Anak Usia Dini di Masa Pandemi Covid 19 melalui Alat Permainan Edukatif Papan Pintar dari Kulit Kerang. Journal on Early Childhood, 22 - 27. doi:https://doi.org/10.31004/aulad.v4i1.92

Tambunan.,S.Par.,M.Sc1, E., \& Masatip.,S.Sos.,MM.Par, D. (2020). Konsep Augmented Reality Sebagai Pengembangan Pemasaran Pariwisata dalam Menghadapi New Normal Masa Pandemi Covid-19. Jurnal Ilmiah Akomodasi Agung, 7(2). doi:https://doi.org/10.51827/jiaa.v7i2.47

Umal, M. K. (2019, Augustus 14). Cara Mendapatkan Aplikasi Unity 3D Dan Aplikasi Pendukungnya. Retrieved from Jokam Informatika: https://jokaminformatika.com/blog/cara-mendapatkan-aplikasi-unity-3d-dan-aplikasipendukungnya-untuk-membuat-game-keren/

Wardani, A., \& Ayriza, Y. (2020, ). Analisis Kendala Orang Tua dalam Mendampingi Anak Belajar di Rumah Pada Masa Pandemi Covid-19. Jurnal Obsesi : Jurnal Pendidikan Anak Usia Dini, 5(1), 772-782. doi: 10.31004/obsesi.v5i1.705

Yudia, A. P., Yudiemawati, A., \& Maemunah, N. (2018). Pengaruh Pemberian Stimulasi Oleh Orang Tua Terhadap Perkembangan Bahasa Pada Anak Usia Toddler Di Paud Asparaga Malang. Jurnal Ilmiah Keperawatan, 3(1). doi:https://doi.org/10.33366/nn.v3i1.828 